Meta

Journal des traducteurs

Translators' Journal

\title{
Translation of Horror
}

\section{Amela Simic}

Volume 45, numéro 1, avril 2000

La traduction littéraire au Canada

Literary Translation in Canada

URI : https://id.erudit.org/iderudit/004147ar

DOI : https://doi.org/10.7202/004147ar

Aller au sommaire du numéro

\section{Éditeur(s)}

Les Presses de l'Université de Montréal

\section{ISSN}

0026-0452 (imprimé)

1492-1421 (numérique)

Découvrir la revue

\section{Citer cet article}

Simic, A. (2000). Translation of Horror. Meta, 45(1), 155-157.

https://doi.org/10.7202/004147ar

\section{Résumé de l'article}

Cet article est un essai personnel relatant mes débuts en traduction et explique comment les motivations me poussant vers cette profession ont changé au fil des événements de ma vie en ex-Yougoslavie pendant la guerre.
Ce document est protégé par la loi sur le droit d'auteur. L'utilisation des services d’Érudit (y compris la reproduction) est assujettie à sa politique d'utilisation que vous pouvez consulter en ligne.

https://apropos.erudit.org/fr/usagers/politique-dutilisation/ 


\title{
Translation of Horror
}

\author{
AMELA SIMIC \\ Traductrice, écrivain et journaliste
}

\section{RÉSUMÉ}

Cet article est un essai personnel relatant mes débuts en traduction et explique comment les motivations me poussant vers cette profession ont changé au fil des événements de ma vie en ex-Yougoslavie pendant la guerre.

\section{ABSTRACT}

This article is a personal essay on how I started to translate and how my motives changed with the changes of life circumstances during war in ex-Yugoslavia.

\section{MOTS-CLÉS/KEYWORDS}

Yougoslavie, traduction littéraire, réflexions sur la guerre

"We are still alive." This was the ending of hundreds of letters I sent out to friends from Sarajevo, the city I had lived in almost all my life, including the three years of siege. The siege and killings did not end with my departure, but in my backpack, along with photograps, letters and a few cherished books, I brought the war with me to my adopted country. It is invisible to anyone but myself and a few people with whom I share the experience. We never talk about it, but its mark is in our mutual memories, in our nightmares and in the different connotations that some words or phrases acquired through it.

The world, imperfect as it is, has always existed. But for me, killings and atrocities happened only in books or in films. And even when I found myself in the middle of the chaos of war, for a long time I thought that I would awake into a beautiful spring morning and realise it was all a bad dream. But that never happened. In those years, my life was spinning around one word: survival. On the one hand, it meant coping with life without water, electricity and with very little food, queuing up for hours to get basic things that are normally taken for granted, under incessant shell and sniper fire. On the other, it meant trying to understand, translating horror in order to externalise it.

Fear: apprehension, dread, terror...

I sit for hours, listening to the sounds of war, surrounded by dictionaries, and make lists of words that have suddenly become part of my existence.

Vandalism, barbarism, slaughter...

My foolish mind thinks that, armed with words, I am protected from all the horrors around me.

A fugitive from reality, I find shelter in a foreign language. How do you say sorrow in different languages? Life? Death? Sea? I strain my eyes in the feeble candlelight, leafing through dictionaries and making lists of these words, as if my life depended on it. 
Mortar, cannon, grenade, automatic rifle, bazooka, machine gun, rocket launcher. If I can match all of these with sounds, if I can translate them into English, they will become harmless.

Combing lice from my child's hair, I translate the situation into English, turning the misery I live in my mother tongue into an anecdotal memory in English. That is when I decide to adopt English as the language of my memories.

Translating hopelessness and sorrow alienates these feelings. As if they belong to somebody else. The simplicity and restrictions of my vocabulary, intentional avoidance of complex sentences for the lack of knowledge detach me from the experience.

I make long speeches, tell war stories to an imaginary audience, using a foreign language as one uses tools: a film-maker his camera, a sculptor his chisel, a soldier his gun. I cannot cry in English. I cannot pity myself in English.

I like to believe that I started translating when I was two years old. We lived in Naples, Italy at the time and while my parents were polishing their Italian at the University, I was spending days with the neighbour, a big woman who laughed a lot and taught me Neapolitan. So, when I would go out with my parents on weekends, I would bargain with street vendors for them, because they couldn't understand a word of this strange dialect. By the time we left Italy, two years later, I could shut myself in this new language and pretend to be somebody else. I invented not only words that resembled my adopted dialect, but a whole new world, entirely my own.

My aunt initiated me into literary translation when I was five. She studied English and German literature. In the summer, we would stay in my grandparents' house by the sea. She would prepare her exams and I would quietly sit in her room and read my books. Then she would take a break and read poems to me in the original and in translation. I would repeat after her and learn them by heart. From then on, the excitement of reading, writing, learning new languages and translating permeated my life. I translated prose and poetry because I wanted other people to read them. I wanted to present my friends who didn't speak English with the music of written words I had fallen in love with. It became a sacred task to share the pleasure of discovering new writers, new worlds.

I translate my friends' poems that speak of war and send them into the world with my letters. The need to testify is really a hope that a miracle will happen, that someone will read them and come to rescue us.I sit at my desk and type the translations of my friends' poems over and over again on a small portable typewriter. Every time I change something. I show them the new versions and discuss the changes. For the first time, I appropriate somebody else's writing, take the liberty to suggest something else, to change their poems. It is not a process of translating any more, but building new poems over the original ones. They become "our poems." We improve them together, the translation first and then the original. I feel them under my skin, as if I have written them myself.

"These are word-for-word translations, bare bones, they will not appeal to an English audience," my English friend tells me. "You don't understand. These poems are meant to be unadorned records, merely a horrifying testimony."

When I was a student, I used to work for the International Poetry Festival that 
was held in Sarajevo every year and which brought poets from all over the world to the city. One year I had to translate poems (from the English) by a Chinese poet who had been imprisoned for twenty years. His poetry was very simple, almost like nursery rhymes. While working on the poems I thought they lacked something-long descriptions of suffering, poetic flourishes. The world of his poems was built on common, everyday words. Only when I read them aloud, to the audience, I realised how chilling they were, how all those big things I was looking for in vain had been there all along, in the silences, between the lines.

When I would hear the word "shell" I would think of the sea. But that was in the past, in my life before the war.

When I say the word "shell," I think of those thousands of pieces of metal that penetrate human bodies, each having the capacity to kill. When will a rose cease to be the imprint of an exploded shell in the asphalt and become again a fragrant flower from my grandfather's garden?

The words haven't changed. My life has changed their meanings. 